\title{
Fuel-Cell Integration on Board Surface Ships
}

David Ignacio Fuentes ${ }^{1}$

Hernán de Lavalle Pérez ${ }^{2}$

\begin{abstract}
Given the high levels of air pollution around the world, produced by the emission of greenhouse gases, the shipbuilding industry is in search of a "zero emissions" ship. To achieve this, research groups, have focused on the further investigation of the fuel cells. These devices can produce energy by only using hydrogen and oxygen as main power sources, having the next advantages features: low noise production, no emissions, and high efficiency. They can also be integrated with other systems. As Jules Verne wrote in his "The Mysterious Island", one day water will be used as fuel. The hydrogen and oxygen that constitute it, used alone and simultaneously, produce inexhaustible heat source and light intensity much greater than that of coal.
\end{abstract}

Key words: Alternative energy, fuel cells, greenhouse effect gases, generator, PEMFC.

\section{Resumen}

Teniendo en cuenta los altos índices de contaminación atmosférica alrededor del mundo, producida por la emisión de gases de efecto invernadero, la industria de la construcción naval está en la búsqueda del buque de "cero emisiones"; para el logro de este noble objetivo, los grupos de investigación sobre el tema han enfocado como objetivo las celdas de combustible. Estos dispositivos tienen la capacidad de producir energía sólo con el uso del hidrógeno y el oxígeno, además, producen poco ruido, ninguna emisión y alta eficiencia; mientras que pueden integrarse con otros sistemas. Tal y como lo visionó Julio Verne en su obra "La Isla Misteriosa", creo que el agua se usará un día como combustible, que el hidrógeno y el oxígeno que la constituyen, utilizados aislada y simultáneamente, producirán una fuente de calor y de luz inagotable y de una intensidad mucho mayor que la de la hulla.

Palabras claves: Energía alternativa, celdas de combustible, gases efecto invernadero, generador, PEMFC.

Date Received: May 21th, 2014 - Fecha de recepción: 21 de mayo de 2014

Date Accepted: June 30th, 2014 - Fecha de aceptación: 30 de junio de 2014

\footnotetext{
${ }^{1}$ Teniente de Navío . Escuela Naval de Cadetes "Almirante Padilla", Colombia. e-mail: fondexx@hotmail.com

${ }^{2}$ Teniente de Navío . Escuela Naval de Cadetes "Almirante Padilla”, Colombia. e-mail: delavalleperez@gmail.com
} 


\section{Introduction}

The naval construction industry is committed to the scientific search for new forms of alternative and clean energy to be in tune with the 1973 international convention to prevent pollution from ships, which was modified by the 1978 protocol, also known as MARPOL 73/78. The final objective is a ZERO-EMISSIONS ship; inasmuch as this progress is produced, interest for fuel cell technology has extended significantly. An increasing number of research groups have felt the need to participate in said projects, their need for a single, complete, and up-to-date exposition to the technology and its applications have become evident, and it is widely registered in research on the theme around the world in different disciplines. While fuel cells are the key component to develop the production of a cleaner energy alternative, it is essential to understand their characteristics.

\section{How do fuel cells function?}

FFuel cells are devices with the capacity to produce energy, while hydrogen (which acts as fuel) and oxygen (which acts as oxidant) are supplied to electrodes. These devices have the following principal characteristics: low noise level, little or no emission of contaminating gases, and high efficiency; in addition, it may be integrated with other systems for them to work as principal or secondary input source. A fuel cell functions much like a battery, "its functioning is based on the electrochemical reactions between a fuels, in this case a gas rich in hydrogen, and an oxidant, in this case oxygen from the air, with no intermediate combustion cycle. It produces energy in the form of electricity and heat and as sub-product, it generates water $100 \%$ pure; does not emit pollutants".

Fuel cells are composed of two electrodes, the cathode (positive) and the anode (negative), with an intermediate membrane (catalyst). Hydrogen enters through the anode and is divided in the

1 DOMÍNGUEZ, Juan José. Celdas combustibles (I). En: Anales de mecánica y electricidad. Madrid: Asociación de ingenieros de ICAI. Marzo-abril, 2002 p. 14. catalyst into $\mathrm{H}+$ positive ions and electrons, oxygen from the air enters through the cathode and in the presence of the catalyst is divided into O2- negative ions; the positive hydrogen ions leave through the electrolyte in direction to the cathode leaving the free electrons in the anode and upon properly connecting the anode and the cathode, the electrons left by the hydrogen will travel this path, producing current. In the negative pole, the oxygen, with the ions left by the hydrogen and the electrons turn into water.

Theoretically, the voltage produced by a fuel cell ranges between 1 and $3 \mathrm{~V}$, but in reality "it will be from 0.6 to $0.85 \mathrm{~V}$ due to losses produced within the cell" 2 ; to achieve the desired voltage, a bank is formed, that is, a set of cells that when correctly connected provide the voltage mentioned. Normally, the cell's output voltage is of continuous current, which is why at the cell output or that of a set of cells an inverter or transformer must be installed to turn it into alternate current for its use and distribution.

\section{Why use fuel cells?}

A fuel cell is an environmentally friendly source of energy; additionally, fuel cell systems do not contain moving pieces, making them more reliable and efficient. These fuel cells emit ultralow emissions or zero emissions, have high energy conversion efficiency, low noise level, low vibration, and low or null levels undesired exhaust gases, except if hydrogen is produced through a reformed hydrocarbon process, which has carbon compounds as sub-products ${ }^{3}$.

Fuel cells can deliver around 10 times more electric energy than that delivered by a lithium-ion battery, with the same volume. The fuel of the cells does not degrade over time and may function in a broad range of temperatures $\left(80\right.$ to $1600{ }^{\circ} \mathrm{C}$ ); it can be quite safe and without elimination problems,

${ }^{2}$ DOMÍNGUEZ, Juan José. Celdas de combustible (I). En: Anales de mecánica y electricidad. Madrid: Asociación de ingenieros de ICAI. Marzo-abril, 2002 p. 15.

3 Luckose, L (et al). Fuel cell propulsion system for marine applications. 1st edition. The United States: Elsevier publications, 2011. p 01. 
Fig. 1. Schematic diagram of an individual fuel cell.

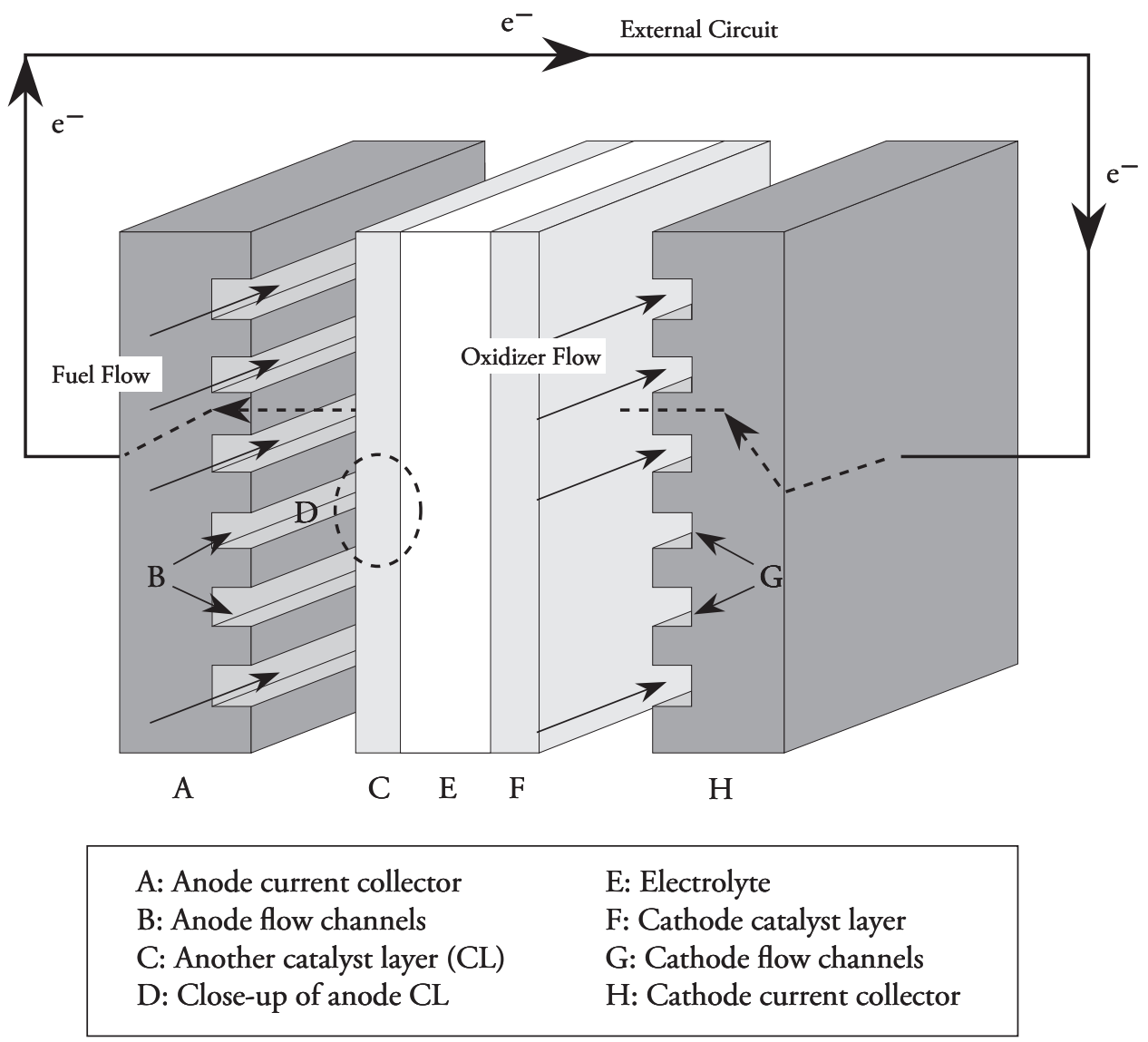

Source: Fuel cell adoption on board merchant ships, p. 17.

and may also provide high energy density, which would lengthen operation times. Fuel cells convert more chemical energy from the fuel in electric energy than that of a diesel generator motor due to its electrochemical isothermal reaction and from which is subtracted the loss of energy through radiation; these have greater efficiency at partial charge and few maintenance requirements. Unlike motors or batteries, fuel cells do not need recharging because they maintain a fuel flow reacting internally in the cell, which is why in some groups these are called flow batteries. These attributes of the cell's fuel make it attractive for the propulsion of an environmentally friendly ship project. ${ }^{4}$

\footnotetext{
${ }_{4}$ Luckose, L (et al). Fuel cell propulsion system for marine applications. 1st edition. The United States: Elsevier publications, 2011. p. 2.
}

\section{Type of fuel cells}

A variety of fuel cells are in different stages of development, the most common classification of fuel cells is by the type of electrolyte used in the cells, thus: polymer electrolyte membrane fuel cells (PEMFC), alkaline fuel cells (AFC), phosphoric acid fuel cells (PAFC), molten carbonate fuel cells (MCFC), and solid oxide fuel cells (SOFC). For marine propulsion, the fuel cell is selected based on the following criteria. In the first place, the fuel cell selected must fit in the space assigned within the ship for propulsion systems, to adjust to the space available; likewise, it must have a high energy density. The fuel cell must operate at low temperatures, given that this helps to quickly start the system, control current residues, and it must allow the crew to operate near the device; lastly, the type of fuel cell must be available in the 
market. The characteristics mentioned influence upon the type of fuel cell and their application is recommended in the ship project.

Bearing in mind the factors mentioned, PEMFC offer the best option to integrate fuel cells on board units afloat, given that these operate at low temperatures $\left(60-80{ }^{\circ} \mathrm{C}\right)$, which impacts upon a fast start up and shutdown, will work even when they have not reached their normal operating temperature, do not present corrosion problems because their electrolyte membrane is a solid polymer, and have a long life (50,000 hours). The PEMFC modules have an output power of 30 to $40 \mathrm{KW}$ and have operated successfully in class 212 submarines from the German and Italian navies. These PEMFC attributes make them suitable to function on board the ship.

\section{Application on board}

In the commercial marine sector, fuel cells were initially used on board yachts and fishing boats; thereafter, these systems have been brought to cargo and passenger ships 5 . The United States navy, since the $1960 \mathrm{~s}$, through its research and development programs, has sought its implementation in warships; in Germany, since

5 VOGLER, Finn. and WÜRSIG, Gerd. New Developments for Maritime Fuel Cell Systems, Germany: Germanischer Lloyd AG. p. 5 . the 1970s, it was observed that fuel cells are an effective way of producing energy and power on board their submarines without need to recharge their batteries through diesel combustion; this was the first time this was tested on a submarine with crew and $100 \%$ naval equipment, complying with all the power requirements needed on board. In the 1980s, the Canadian Department of Defense conducted important research for the use of these power production media on board floating units. In 1996, Germany again implemented a fuel cell system on a fishing fleet to make this trade more environmentally friendly. Work is in progress throughout the world on the best way to produce energy and power for ships without damaging the environment. Fig. 2 shows the number of research projects on fuel cells on board surface units; it may be noted that in 2009 research projects increased considerably, which indicates the rising optimism and acceptance of this form of energy production.

\section{Options to integrate fuel cells onto surface ship}

Starting from an all-electric ship (AES), systems may be found where the vessel has two propulsion modes, one would be a propulsion system where power is provided by a diesel generator motor through a transformer; another form of supplying the propulsion power needed by the ship may be from two battery banks that conveniently

Fig. 2. Research projects on fuel cells.

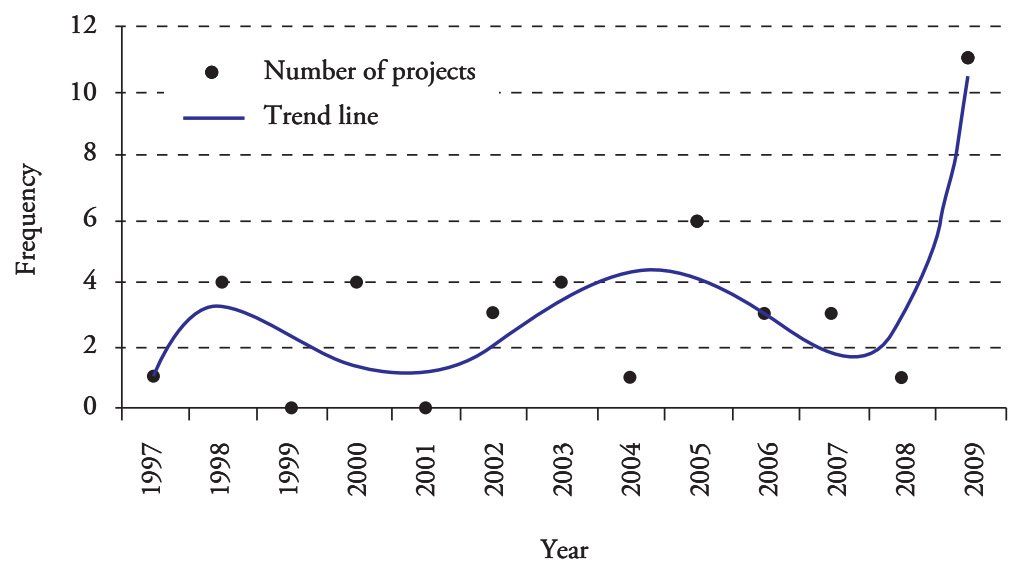

Source: Fuel Cell Adoption on board merchant ships, p. 19. 
connected deliver the necessary power to move the electric motor; these modes of operation have some limitations that yield as a result reduced operational efficiency. As mentioned, propulsion power is supplied by the diesel generator motor and by the batteries; this generator motor produces electricity through the combustion of diesel fuel. Said process has as sub-product harmful emissions onto the environment. Additionally, the diesel generator also has problems of limited energy production and sensitivity to harmonic current consumption ${ }^{6}$. Furthermore, batteries have disadvantages, for example, taking as reference the batteries in Colombian submarines, such require recharge times of approximately two hours and their use time is limited, approximately eight hours; in addition, the battery's charge system introduces harmonic distortion on the $\mathrm{AC}$ side of the power system. Impedance of the diesel generator in combination with non-sinusoidal current feedback of the battery chargers produces voltage distortion that limits the functionality of the power system.

\section{Option 1 - Replace one or several batteries} with fuel cells.

The principal advantage of option 1 is a lower

6 U.S. Congress, Office of Technology Assessment, Marine Applications for Fuel Cell Technology-A Technical Memorandum, OTA-TM-O-37 (Washington, DC: U.S. Government Printing Office, February 1986). p. 8 dependence on power supplied by the fuel cell. Each battery bank replaced by a fuel cell module must comply with the same voltage and current requirements as the pre-existing battery bank; in summary, this option has fuel cells in parallel with batteries, which impacts upon the system's response time due to source differences. Currently, fuel cells are not directly controlled causing disarrangement between the fuel cell and battery impedances, which makes it difficult to implement power systems that have fuel cells in parallel with the batteries.

The voltage of the fuel cell module varies between $440-800 \mathrm{~V}$; depending on the charge condition, it requires a complex control system to adjust the voltage of the fuel cell module to coincide with the battery voltages. Another disadvantage for this option is that the space available by eliminating a series of batteries is not sufficient to house the fuel cell modules and the power conditioning system.

The efficiency of the power system with this option is low and emissions are high because the diesel generator is still in the system; besides, this option does not solve the problem of harmonic distortion from the battery's charge system and the operation time of the batteries is limited; Fig. 3 shows a power flow diagram for option 1.

Fig. 3. Power flow diagram for option 1.

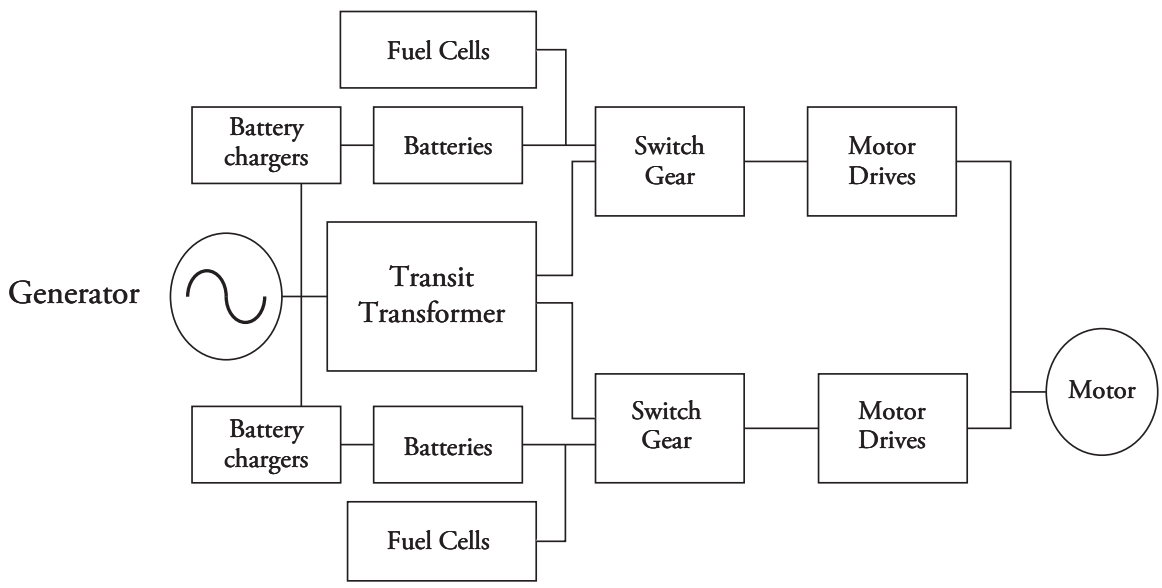

Source: fuel cell propulsion systems for marine applications. 2011. First edition. p 04. 
Option 2 - Substitute all the series of batteries with fuel cells.

This option permits completely eliminating the batteries and the continuous current charge system, leaving the propulsion totally dependent on the fuel cells and on the diesel generator motor. The principal advantage of this option is the use of fuel cells instead of batteries, thereby, avoiding the problem of charge times and limited use times of the batteries, also solving the problem of harmonic distortion introduced by the battery charge system. Another advantage is that the system's power density increases given that the fuel cells have a better power density than the batteries.

However, option 2 has some inconveniences; first, the space available after eliminating the battery banks cannot accommodate the fuel cell modules, the fuel storage system, and conditioning of the system's power; the efficiency of the power system in option 2 is low due to the presence of the diesel generator. As with option 1, in this option emissions are high because the diesel generator is still part of the system; the power flow diagram is shown in Fig. 4.

Option 3 - Replace the whole energy system with fuel cells.

This option allows the energy system to work with only fuel cells. The main advantage of this option is having a power system completely operated by a renewable source of energy; this option makes the energy system highly reliable. The operating temperature of the power system is below $80^{\circ} \mathrm{C}$. All the battery banks have to be replaced by fuel cell modules and a DC - DC converter to isolate the system.

Option 3 turned out to be a highly efficient power system with low emissions, given that it is fully dependent on fuel cells. By implementing option 3 , it is possible to avoid the problem of harmonic distortion introduced onto the system by the battery charger; in addition to solving the problem of voltage distortion. It is important to keep in mind some technical considerations in executing this option; firstly, fuel cell modules must be connected in parallel to satisfy the needs of the system's current, upon connecting the fuel cells to a bus ${ }^{8}$ in parallel, a high possibility exists that the current is sent back to the fuel cell modules, which can reduce the useful life and service efficiency of the fuel cell modules, thereby, current return should not be permitted to the fuel cell modules?

To simplify the analysis of the fuel cell modules during the conformation of the banks, it is assumed that the modules have similar characteristics, such as equal impedance, equal capacity of charge delivery, and equal response time; nevertheless,

\footnotetext{
BRANDON, Nigel and THOMPSETT, Dave. Fuel cell compendium. First edition. London: Elsevier Inc.

2005. p. 89 .

8 El bus (o canal) es un sistema digital que transfiere datos entre los componentes de un sistema o entre sistemas.

9 W. Shireen, H. Nene "Active Filtering of Input Ripple Current to Obtain Efficient and Reliable Power from Fuel Cell Sources," in proceedings of IEEE International Telecommunications Energy Conference, pp.1- 6 (2006).
}

Fig. 4. Power flow diagram for option 2.

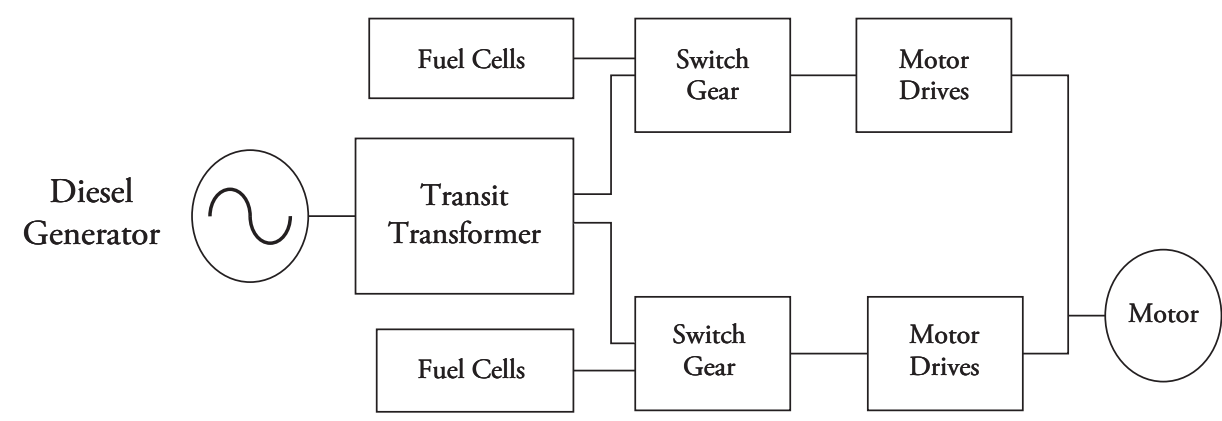

Source: fuel cell propulsion systems for marine applications. 2011. First edition. p 05. 
given that the impedance does not coincide, some modules deliver more current in the bus than the rest, which is why a control system must be installed, Fig. 5 shows the power flow diagram for option 3.

Fig. 5. Power flow diagram for option 3.

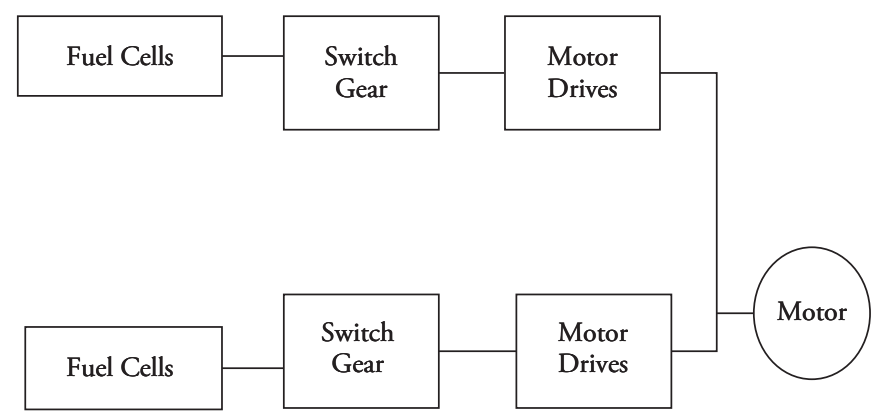

Source: fuel cell propulsion systems for marine applications. 2011. First edition. p 05.

\section{Selection of the fuel cell integration option}

The comparison parameters show the advantages and disadvantages of each option, the complexity of the control system to implement the options, efficiency, and emission levels. The comparison of the three fuel cell integration options is shown in Table 1.

Comparison of the three options shows that option 3 is the most advantageous; option 3 completely substitutes the power system in the ship with a new power system that is totally dependent on fuel cells.

As a precaution, when the fuel cells work in parallel, a diode must be installed or any other protection in series with the fuel cell modules to block any current circulating among them ${ }^{10}$. Keep in mind insertion of the diodes adds further losses to the system. Fig. 6 illustrates an example of a fuel cell integration bus for option 3 .

${ }_{10}$ B. Ozpineci, L. M. Tolbert, Z. Du, "Multiple Input Converters for Fuel Cells," IEEE Industry Applications.

Table 1. Comparison of fuel cell integration options.

\begin{tabular}{|c|c|c|c|}
\hline & Option 1 & Option 2 & Option 3 \\
\hline Advantages & Less dependence on fuel cells & $\begin{array}{l}\text { Without batteries or battery } \\
\text { charge system }\end{array}$ & $\begin{array}{l}\text { Power system totally operated } \\
\text { with renewable energies }\end{array}$ \\
\hline Disadvantages & $\begin{array}{l}\text { Fuel cells in parallel with } \\
\text { batteries; the diesel generator } \\
\text { is still in the system. }\end{array}$ & $\begin{array}{l}\text { The generator is still in the } \\
\text { system }\end{array}$ & $\begin{array}{l}\text { Requires } 8 \text { fuel cell modules } \\
\text { and a } 12-\mathrm{V} \text { DC-DC converter }\end{array}$ \\
\hline $\begin{array}{l}\text { Complexity of the } \\
\text { control system }\end{array}$ & High & Low & Low \\
\hline Space & Not sufficient & Not sufficient & Adequate \\
\hline Efficiency & Low & Low & High \\
\hline Emissions & High & High & Low \\
\hline Harmonic distortion & High & Low & Low \\
\hline
\end{tabular}

Source: Elaborated by the authors based on fuel cell propulsion systems for marine applications.

2011. First edition. p. 05. 
Fig. 6. Example of the fuel cell integration bus for option 3 .

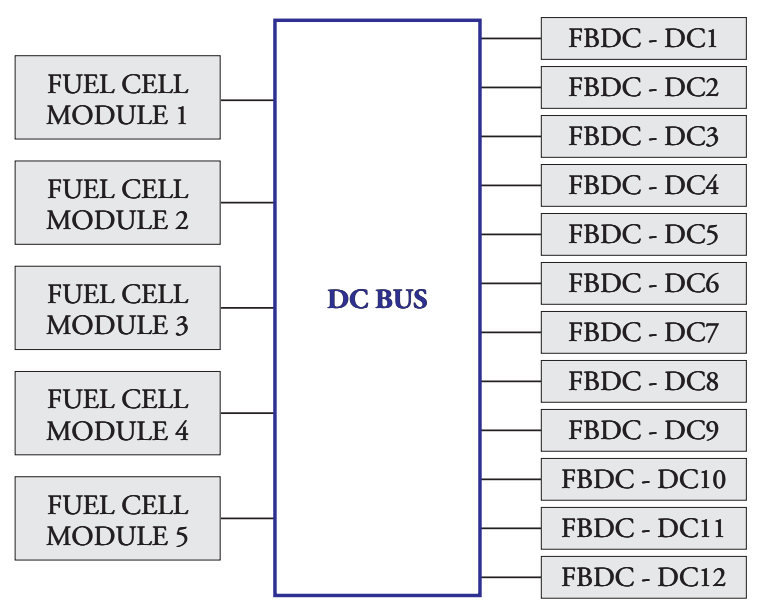

Source: fuel cell propulsion systems for marine applications. 2011. First edition. p 05.

\section{Environmental impact of the system}

The environmental impacts of the system functioning with fuel cells are practically zero, inasmuch as the yield of the chemical reaction taking place within the PEM-type cell is pure water. These devices operate silently, hence, they do not produce noise pollution and are environmentally friendly, given that they do not produce emissions, like greenhouse gases that are inclined to contribute to global pollution; another favorable point is the reuse of the resulting water for services on board the unit or even for refrigeration of the cell's own modules, thus, helping to maintain an operating temperature between 60 and $70^{\circ} \mathrm{C}$.

The electrodes of all fuel cells function with hydrogen, no matter what fuel is being supplied to the fuel cell system. In indirect input fuel cells, the hydrogen carrier (methanol, ammonia, hydrazine, etc.) must first be converted with certain efficiency, also producing secondary products (equivalent to amounts of $\mathrm{CO}_{2}$, in case of hydrocarbon conversion).

By using a fuel cell system in a ship, in any case, pollution through emissions will be further reduced due to the high conversion efficiency. Table 2 shows a comparison of emissions per type of energy production. These comparisons show that the PEM fuel cell is the most suitable for these types of vessels.

The advantages in $\mathrm{CO}$ reduction, in general, are quite believable for the case where coal, oil, or natural gas are used by power stations primarily for electricity production and then used for electrolysis to produce hydrogen. Of course, specific circumstances must be carefully labeled

Table 2. Comparison of emissions by type of system. (gm/HP Hr @100\% of power)

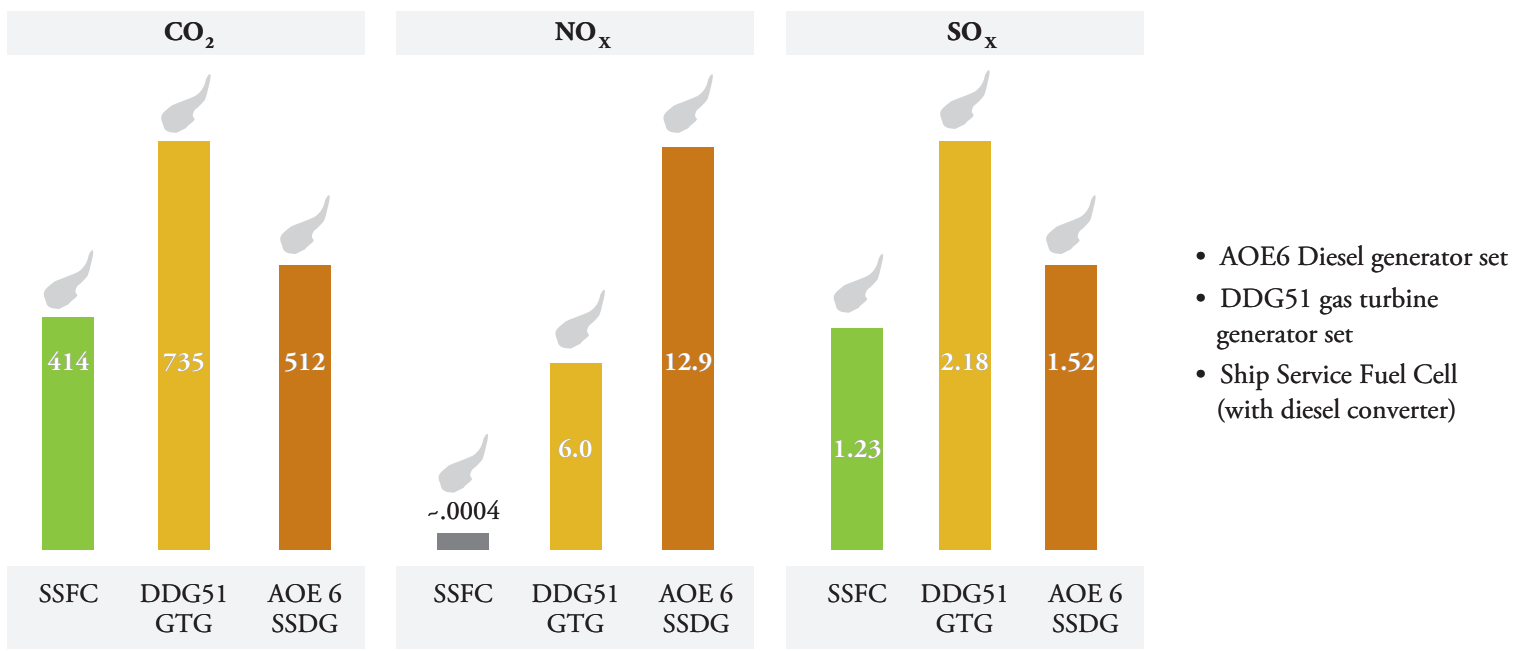

Source: http://www.fuelcelltoday.com/analysis/industry־review/2011. 
to reach valid comparisons. Only energy values ${ }^{11}$ are indicative of the actual efficiency of the whole conversion chain. $\mathrm{No}_{2} \mathrm{CO}_{2}$ pollution exists with electric energy production through hydraulic, nuclear, wind energy or from solar installations.

However, energy considerations will also count with the $\mathrm{CO}_{2}$, which was produced during the cement production for the water dam or for nuclear containment, through silicon fusion, etc. The risk is that these calculations go too far, which may be counterproductive for any technology. A hypothetical case is, for example, the issue of what part of the energy used for roadway and bridge construction should be counted as $\mathrm{CO}_{2}$ source due to the existence of automobiles or trains as necessary means of transport.

\section{Conclusions and Recommendations}

Fuel cells are a promising technology and, upon considering all the types of fuel cells, it is noted that PEMFC are the most suitable cells for naval applications because of their low operating temperature, long operation times, and fast service time.

In relation to the environmental impact of fuel cells, their operation on board units afloat would be completely environmentally friendly, given that as such their functioning is due to a soundless electrochemical reaction occurring within the modules. The result of these reactions is pure water $\left(\mathrm{H}_{2} \mathrm{O}\right)$ and $\mathrm{CO}_{2}$ in minimum quantities, this latter only in cases implementing fuel cells that obtain hydrogen from methanol conversion. Regarding the working temperature of $50^{\circ} \mathrm{C}$, which besides being ergonomically viable for its operators is a key factor for tactical and combat operations due to its low thermograph signature; likewise, its low noise level will reduce the ship's acoustic signature and improve the sound conditions of engine rooms. Fuel cell technology needs to be installed massively to make it more commercial.

\footnotetext{
11 Exergy is the portion of energy that can be transformed into mechanical work; the remaining part without practical utility is called anergy or entropy.
}

Given the versatility of the fuel cells, these may not only be used as energy generation for propulsion, but may also be installed as energy generation for different services on board, like navigation equipment, galleys, on board comfort, among others.

It is worth to continue studying the possibility of implementing this technology, not only in power production on board, but in the production of electricity to units away from urban centers to preserve the environment and, thus, give future generations a healthier world.

\section{References}

[1] DOMÍNGUEZ, JUAN JOSÉ. Celdas combustibles (I). En: Anales de mecánica y electricidad. Madrid: Asociación de ingenieros de ICAI. Marzo-abril, 2002 p. $14-18$.

[2] BRANDON, NIGEL and THOMPSETT, DAVE. Fuel cell compendium. First edition. London: Elsevier inc. 2005. 639 p.

[3] VOGLER, FINN. and WÜRSIG, GERD. New Developments for Maritime Fuel Cell Systems, Germany: Germanischer Lloyd AG. $10 \mathrm{p}$.

[4] U.S. CONGRESS, Office of Technology Assessment, Marine Applications for Fuel Cell Technology - A Technical Memorandum, OTA-TM-O-37 (Washington, DC: U.S. Government Printing Office, February 1986). $39 \mathrm{p}$.

[ 5 ] LUCKOSE, 1 (et al). Fuel cell propulsion system for marine applications. 1st edition. USA: Elsevier publications, 2011. 7 p.

[ 6 ] B . OZPINECI, L. M. TOLBERT, Z. DU, "Multiple input converters for fuel cells," IEEE Industry applications society annual meeting, October 3 - 7, 2004, Seattle, Washington, $797 \mathrm{p}$. 
[7] Fuel Cell Today [online]. Hertfordshire, UK.: [Cited 06 November 2011]. Available in: <http://www.fuelcelltoday.com/ analysis/industry-review/2011/the-industryreview-2011> 